http://doi.org/10.24867/IJIEM-2019-1-081

\title{
The Evolution of Controlling in Companies in Croatia - a Longitudinal Study
}

\author{
Nidžara Osmanagić Bedenik \\ Tenured University Professor, Faculty of Economics and Business, University of Zagreb, Kennedyjev trg 6, \\ 10000 Zagreb, Croatia, nosmanagic@efzg.hr \\ Mirjana Pejić Bach \\ University Professor, Faculty of Economics and Business, University of Zagreb, Kennedyjev trg 6, \\ 10000 Zagreb, Croatia, mpejic@efzg.hr
}

Received (27.11.2018.); Revised (29.01.2019.); Accepted (19.02.2019.)

\begin{abstract}
Controlling is primarily a phenomenon found in practice. The interesting question of how controlling develops in practice has received respectable attention in research and corresponding literature. In this paper we explore controlling in the light of empirical research. Moreover, the unexplored question of how controlling develops in practice in Croatian companies is the main inspiration for this paper. The objective of this paper is to provide an insight into the role of controlling and its understanding, function, tasks, instruments and information flow. We analyse the perceived contribution of controlling to business success as well as incentives and obstacles to its development. This study is based on the analysis of primary data with the aim of describing the development of controlling (explorative study). The research study covers the time span of 15 years in three different points in time: 2001, 2007 and 2015. The study is a retrospective longitudinal study, and this allows us to explore the process of change related to particular aspects of controlling. The study is at the same time a trend study since it enables the analysis of changes at the level of the researched sample. In this paper, we observe, describe and explain findings from the controlling practice in Croatian companies. Our results show that controlling in Croatian companies is most frequently understood as assurance of management rationality. In general, operative tasks and operative instruments dominate with internally-oriented focus. What is still needed is a more strategic and normative orientation, more external orientation and more freedom for controllers to create tasks and activities. Controlling is also recognized as a business success factor in Croatian companies. Management has the main influence over the development of controlling while IT support is discovered as the main obstacle in its development. The contribution of this paper is threefold: firstly, we provide insight into the controlling function; secondly, we explore the dynamic perspective in controlling over the last 15 years in Croatian companies, and thirdly, with this paper we hope to provide design guidelines and recommendations that have to be concretized in organizations by taking into account the specific conditions of each individual case.
\end{abstract}

Key words: understanding of controlling, controlling tasks, controlling instruments, information flow incentives and obstacles, Croatian companies

\section{INTRODUCTION}

The practise of controlling has a very rich history. Early empirical studies date back to 1974 and inform us that $90 \%$ of 30 typical large German companies have a Controlling department [10]. Since then, many different research studies have proved a wide acceptance of controlling in the business practice. [10; 51; 24] Another very interesting study in this area is the international comparison of controllers' tasks in Germany, France and USA [42]. It stresses budgeting, operational planning and internal reporting as the main tasks in German companies, and financial accounting, cost accounting and budgeting as the main tasks in USA companies. "Like their German colleagues, French controllers are consistently not responsible for the additional accounting and finance-related tasks which occupy most of controllers' attention in the USA." [52]. The comprehensive overview of controlling tasks in controllers' practice ends with this statement: "The core tasks of controlling were - and continue to be designing the planning process, monitoring whether or not goals are achieved, supplying management with relevant information, and providing business support to managers. In spite of all the similarities, controllers' tasks differ from country to country and from company 
to company in an economic region. This is what makes it such a multifaceted subject." [52].

This paper provides empirical research results related to controlling in companies in Croatia in the period 2001-2015. This study investigates the acceptance, position, role and understanding and possible changes of controlling in companies in Croatia in the past 15 years. Moreover, we explore changes in tasks, instruments and information sources and users of controlling, which gives us an insight in the function of controlling in the analysed period. Our guiding question is whether, and how, controlling has changed. Therefore, the aim of this study is to provide empirical evidence on controlling in companies in Croatia. This study is built on empirical research methodology developed by Osmanagić Bedenik [26; 27; 28] on controlling in companies in Croatia. The authors of this paper use the same methodological approach as in the research study conducted in 2015, which enables comparison of results in the entire period 2001-2015, thus reflecting the empirical evolution of controlling in Croatia.

This study provides a theoretical and empirical contribution to the field. From the theoretical point of view, this paper offers the academic community interesting insights into empirical understanding of controlling and its changes. It therefore contributes to the existing literature. From the empirical point of view, this study with its relevant results provides understanding and learning from the practice and enables national and international comparison of the controlling experience while offering a basis for comparison. The target audience for this paper includes scholars who might be inspired by this new research idea. Since our results originate from the controlling practice, this study could be interesting for managers and owners, members of supervisory boards and experts as well.

The structure of this paper is as follows: after this introduction, section 2 provides a brief overview of empirical research studies and empirical understanding of controlling. Section 3 presents the empirical approach, data sources and methods. The empirical results are provided in section 4. Finally, section 5 encompasses the conclusion and contribution of this paper.

\section{EMPIRICAL UNDERSTANDING OF CONTROLLING}

Although almost every large company has a controlling department, no widely and internationally accepted definition of controlling exists $[30 ; 1 ; 6 ; 22 ; 2 ; 51]$. Rich literature on controlling has not yet created a widelyaccepted definition. [2; 35; 10;17; 6; 28; 12; 51) Various systematisation and categorisation models exist depending on the goals of controlling, goals of the company or depending on the understanding of individual authors [25]. The theoretical understanding of controlling can be shown through the following groups of definitions [49]: controlling is often defined as the function of supplying information, as part of management responsible for goal orientation and through the basic task of coordinating different partial management systems. It has to be stressed that different conceptions supplement each other, focusing on different dimensions [36]. However, in the real world, controlling is a 'tailor-made' function; it has to suit concrete managers in a concrete organisation at a concrete time under concrete circumstances. Any change in these determinants of controlling would change its practise and shift its understanding as well. Within the spectrum of controllers' tasks, assuring rationality can be identified as a task type that is not exclusively, but indeed mainly carried out by controllers [52].

New incentives in the understanding of controlling were offered by Weber and Schäffer when they developed an orientation toward business rationality [50]. According to Weber and Schäffer [52] controlling takes over the function of rationality in the form of disburdening (efficient supplying of information as a necessary requirement), complementing (questioning the management activity by means of methodical and professional knowledge) and restricting (in the case of potential opportunistic decisions by the management) [25]. Still, it is generally considered that these new principles are not developed enough and cannot replace the principle of controlling coordination [34].

Since there is no single generally accepted definition of controlling, there is, similarly, no single definition of controlling goals either $[12 ; 52 ; 3 ; 28]$. However, on a general level, authors agree that the main controlling goal is to support management in the process of planning, controlling, reporting, interpreting, evaluating and consulting. The newest research studies compare the understanding of controlling in companies listed at the Frankfurt and Zagreb Stock Exchange and prove that controlling is mainly understood as assurance of management rationality, in German and Croatian companies as well [32]. In addition to different interpretations of controlling in theoretical papers, the following question also arises: What is the experience of controlling in practise?

Controlling is a phenomenon which first originated from practise [16]. Empirical research studies provide knowledge from the real world so that both quantitative and qualitative studies of controlling in practise are encouraged [25]. Different research studies conducted in Germany in the period 1949-1994 provide insight in the tasks of controlling and a change of focus from cost accounting, calculations and operative planning toward counselling, investment budget and cost-effective business operations. Even though the tasks of strategic planning have gained increasing importance, the emphasis is still on the operative dimension of business [52]. The Landsberg/Mayer study [18] also confirms the dominance of operative tasks of controlling: planning and budgeting, participation in the creation and ongoing development of information, decision, planning and reporting systems, monitoring on the basis of plannedvs-actual comparison, reporting and commenting and advising divisional and corporate management. Apparently, strategic tasks are less important. In Austrian companies, the 5 most important controlling 
tasks are: budgetary monitoring + planned-vs.-actual comparison, cost accounting, reporting, budgeting and variance analysis [23].

Empirical research in the area of controlling is very interesting. There are over 30,000 research results of controlling in practise, both in profit and non-profit organisations as well as research conducted at universities in the form of controlling education [56]. There are different ways of discovering the practise of controlling: through personal interviews, written surveys/questionnaires, content analyses and case studies. Such research prevails in Germany and Austria [6]. Empirical research studies in the area of controlling are numerous and they are often presented through doctoral dissertations. For instance, Legenhausen has researched empirical studies in controlling in the period 1970-1990 in the German-speaking area. According to Legenhausen, a total of 17 research studies were conducted on controlling in practise in different branches and companies of different sizes. The sample ranged from 24 to 1174 companies [19].

Controllers, as experts who practice controlling, are often the subject of research studies. Traditionally, research studies explored which characteristics were necessary and desirable, which characteristics were required in job advertisements and how they changed in time $[18 ; 32 ; 36 ; 35 ; 12 ; 52]$. Controlling instruments are often the subject of empirical research studies: indicators, cost accounting and calculation of effects, indepth research of cost accounting, specific use of cost accounting, instruments of operative controlling [19]. Controlling research studies have been growing recently and they are conducted in different business functions: marketing [5], logistics [4], finance [46], reporting [20] as well as in non-profit organizations, controlling benchmarking [47] etc. Even though controlling has become self-evident in profit organizations, there are interesting results from empirical studies on the use of controlling in non-profit organizations as well. Research studies focus on operative controlling and interdependence of the organisational environment, state of development and controlling efficiency. Organisational culture and professionalism of management significantly affect the degree of development of operative controlling. The final result stresses that developed controlling significantly contributes to the success of a non-profit organisation [9]. Moreover, research studies in Croatia show that controlling is a success factor. In other words, with controlling, companies achieve a higher level of success than companies without it $[31 ; 7 ; 53 ; 43 ; 45]$. This is not only valid in companies, but in banks [42], central bank [11], leasing companies [21] and post companies as well [38]. Controlling efficiency and its determinants is another interesting research subject [24]. Successful controllers are focused on business dimensions that are important to managers/company, thereby releasing themselves from less important tasks [47].

Research focussing on the practise of controlling is not only interesting in big companies (Weber 2007) but in smaller ones as well [51]. Attention is given to small and medium enterprises, controlling organisation and tasks, controller reputation as well as the desirable controller profile [38; 14]. Kaland also gives a detailed insight in empirical research in the area of controlling in small and medium enterprises and companies, especially expert retail. This author's extensive research includes the analysis of general conditions in the company and its specific functional areas, the attitude of the management toward controlling, the organisational form of controlling and controlling instruments [13]. International studies are also interesting because they analyse controlling in different circumstances and different cultures [8; 51] as well as other numerous contributions to controlling research.

\section{EMPIRICAL RESEARCH METHODOLOGY}

Inspired by previous research results on controlling in Croatian companies [26; 27; 28; 29] as well as by numerous controlling empirical research studies in European countries [20], our purpose is to provide insights into the development of controlling in Croatian companies during the last 15 years. Our guiding question is: "What does the reality of controlling in Croatian companies look like and how has it changed in the last 15 years?" This is a longitudinal study using the methodology in which data is repeatedly gathered for the companies over a period of time. This longitudinal research project extends over years and enables an observation of dimensions of the evolution of controlling. On such basis, the study addresses the following research questions:

1. How is controlling understood and accepted in Croatian companies?

2. Which controlling tasks dominate in companies in Croatia?

3. Which controlling instruments are most frequently used in companies in Croatia?

4. What is the main source of information for controlling and who are the main users of information from controlling?

\section{Does controlling contribute to business success?}

The sample used in this paper includes mainly large companies in Croatia (with more than 250 employees, more than EUR $4 \mathrm{~m}$ in total income and/or more than EUR $4 \mathrm{~m}$ in assets) in $2001(\mathrm{~N}=70), 2007(\mathrm{~N}=82)$ and $2015(\mathrm{~N}=40)$. Its economic structure is presented in Figure 1. According to the age of organizations in our sample, it could be interesting to mention that between $50 \%$ in 2001 and $57 \%$ in 2015 are organizations with 50 years of business experience or more, between $29 \%$ (2001) and 38\% (2015) have been active between 10 and 50 years, the remaining small number are young organizations with less than 10 years in practice. Our target respondents and their structure in 2015 is as follows: managers and heads of controlling department 
(80\% of respondents) with work experience manly between 6 and 15 years (50\%) and academic education

(MBA $67.5 \%$, postgraduate and doctoral degree $25 \%$ ).

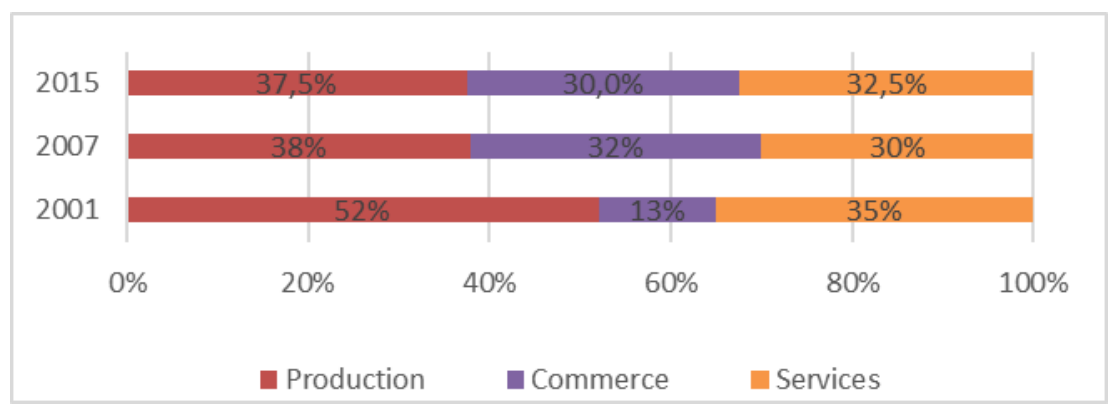

Figure 1. Structure of sample based on the economic field of core business

Data collection was based on a questionnaire with 30 closed questions and offered answers of different grading and intensity. Quantitative and qualitative analysis was conducted with the help of the SPSS statistical package and descriptive statistics.

\section{EMPIRICAL RESEARCH RESULTS}

Our empirical results are divided in several subsections where we present institutional, instrumental and informational aspects of controlling. Moreover, we explore the contribution of controlling to business success as well as incentives and obstacles to controlling development.

\subsection{Institutional aspect of controlling}

From an institutional point of view, there is a close relationship between planning and monitoring, information and management [52]. Controlling can be implemented in two ways: as a philosophy implemented by controlling instruments without a controlling department/unit, or as a controlling department/unit that represents controlling philosophy with corresponding tools. In this paper we explore the existence of a controlling department/unit, its age, its position in the hierarchy and its independence regarding other departments. On such basis, the study addresses the following research question: What does the profile of a controlling department in Croatian companies look like? How has it changed in the last 15 years?

The existence of a controlling department in Croatian companies in the last 15 years is shown in Figure 2. Our findings show a rising importance and role of controlling: while in 2001 only 53\% companies in the sample had a controlling department, in 2007 there were $74 \%$ of them and in 2015 around $90 \%$ companies from the sample had a controlling department. The European experience of controlling as a selfexplanatory function is proven true in Croatian companies as well.

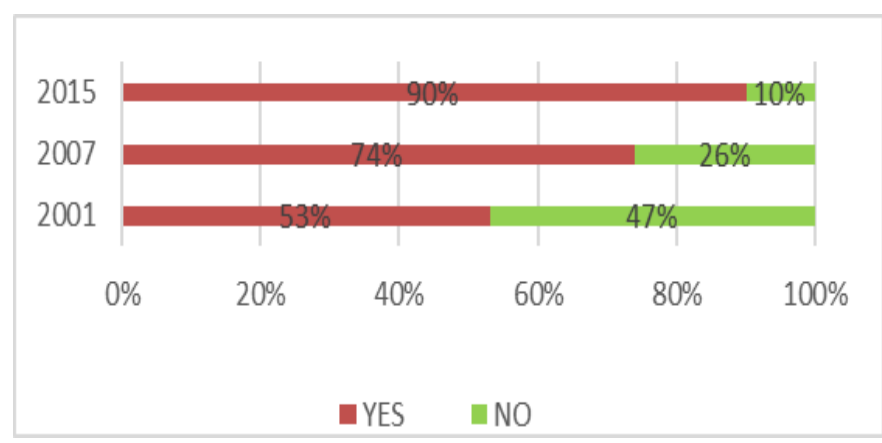

Figure 2. Existence of a Controlling department

Exploring the age of the controlling departments, we got more insights into the evolution of controlling. While in 2001 controlling was mainly being introduced $(26 \%)$ or was a young function up to 3 years old (41\%), in 2007 the controlling department was mostly present for more than 4 years (49\%) and in 2015 there is a respectable experience of controlling for more than 10 years $(52.5 \%)$. Our findings demonstrate the process of wide acceptance of controlling (Figure 3). 


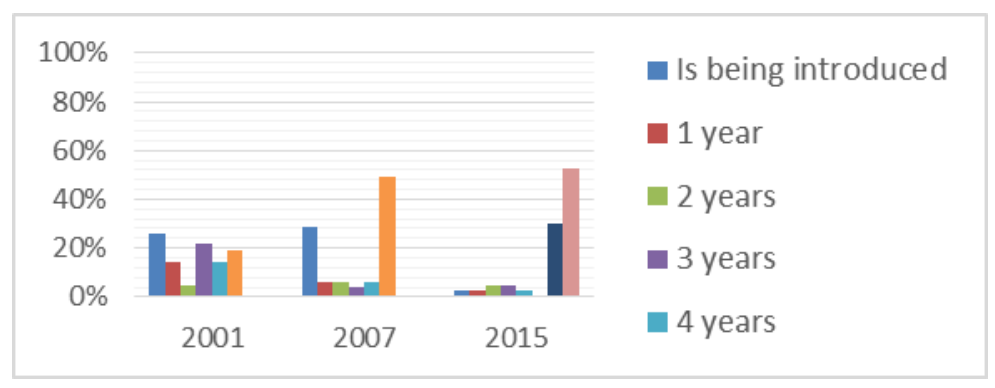

Figure 3. Age of controlling department/unit

During the observed period, the size of the controlling department, measured by the number of its employees, was relatively stable: mostly 3-5 persons worked there. Since the educational level of employees determines the quality of work, we explored the educational level of employees in controlling departments. The findings are presented in Figure 4 . In the analysed period, the controlling departments have strengthened significantly: the share of MBA-educated employees rose from $66 \%$ in 2001 to $90 \%$ in 2015, which is an excellent prerequisite for the quality of controlling work.

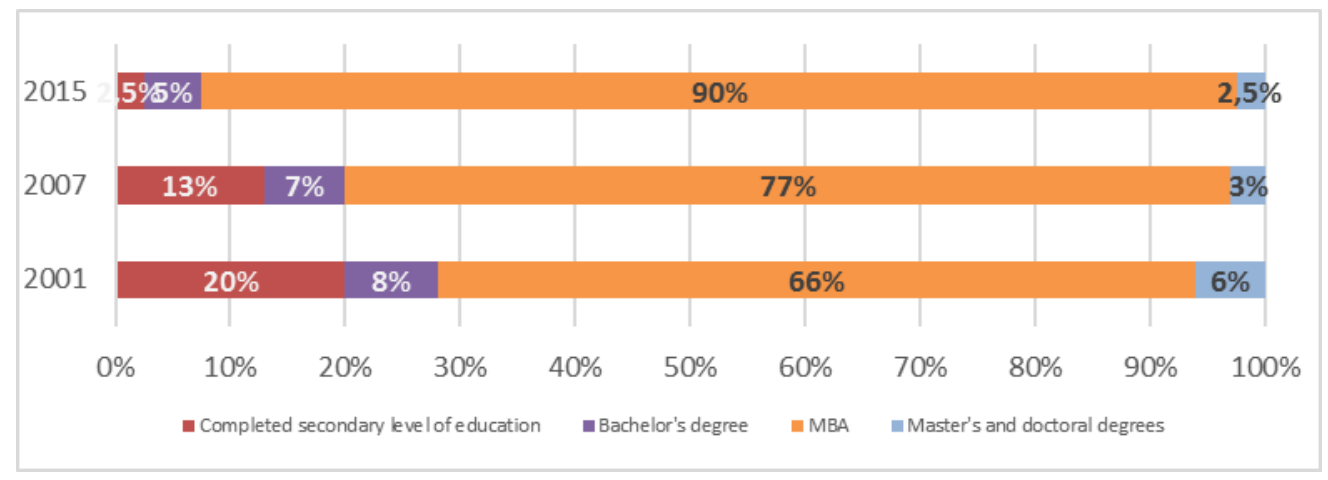

Figure 4. Educational level of employees in controlling department

Institutional independence often means freedom of experts' work. We explore whether controlling departments exist together with a similar department, for instance finance or accounting, or if they are independent. Our findings prove that in the last 15 years controlling has significantly become more independent; separation from other departments ensures focus on controlling experts' work (figure 5).

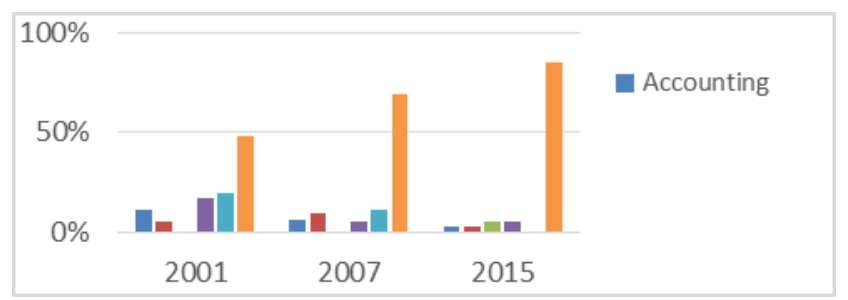

Figure 5. Controlling department/unit independence

Our institutional research would not be complete if we did not mention the function of planning and analysis. Namely, in the previous economic phase in our country, the existence of a planning and analysis department was a good tradition and an important part of the socialist economy. Our commitment in 1991 toward a market economy was often followed by the dissolution of planning and analysis departments in companies. Since management was aware of the benefits of this knowledge, many companies simply renamed Planning and analysis departments into controlling departments. So, in our sample $34 \%$ of Croatian companies (in 2001) and $45 \%$ (in 2015) had controlling departments which had previously been planning and analysis departments, under a different name. With this change, companies have become more modern, but in their core not really changed in their tasks and instruments used. At the same time, many companies, especially new ones, set up new controlling departments, $17 \%$ in 2001 and $45 \%$ in 2015, without any previous historical burdens. So, the controlling landscape in Croatian companies is influenced by the past and by present circumstances as well.

\subsection{Functional aspects of controlling}

The functional dimension of controlling can be discovered exploring the tasks which are executed in 
this department. The main question is: Which controlling tasks dominate in companies in Croatia? Business circumstances, as they change, create new tasks and instruments for business needs and solutions. The operative point of view, which dominated in the 1960s, deals with the efficiency of present potential of success in the company. Its goal is to ensure the best relationship between costs and benefits, namely efficiency. Strategic controlling widens the perspective in the future and focuses on the present building of future potential of success. Effectiveness as the new and wider focus reflects the relationship between the company and its environment. Strategic tasks and instruments were developed from the 1970s. Normative controlling supports normative management, meaning vision, mission, values, culture and other norms regarding stake-holders, corporate governance, corporate social responsibility, compliance, and integrity of company [40]. The normative business dimension with corresponding tasks and tools was developed in the 1990s. Normative controlling encompasses and integrates operative and strategic perspectives into the company's values and principles that last and make each company unique, thus distinguishing it from other companies. Integrative controlling encompasses balance between operative, strategic and normative tasks and tools in the process of setting values, planning, control, reporting, interpreting and evaluating business activities. Contemporary business needs an integrative approach. According to our results, the most frequent tasks are: reporting, control (analysis of deviation), planning and budgeting coordination, integration of partial plans and budget into the organization's plan/budget and cost analysis. Those tasks are authentic controlling tasks, the core of controller's responsibility, defined in 1962 by the Financial Executive Institute [52]. The next group of tasks according to its frequency includes expert assistance and supervision of planning/budgeting process and reasons for variances. The less frequent controlling tasks are categorised in the third group where strategic tasks dominate. It can be concluded that operative controlling tasks are in the focus of controlling activities in Croatian companies. The lack of strategic tasks may have influence on the lack of strategic orientation in companies, or, strategic tasks may be executed in some other function/department. Our results correspond with a similar research study conducted in Austria [6]. The research study of controller's tasks in the largest Croatian companies listed on the Zagreb Stock Exchange [32; 33] presents similar results: the top 5 controlling tasks include operative planning, monthly reporting, checking cost reduction, cost planning \& control, and cost \& budget monitoring \& control. The research project conducted in Croatia in the period 2009-2010 on the sample of 79 companies provides similar results: the 5 top controlling tasks are: operative planning \& control, operative reporting, management information provision, coordination \& integration of planning, control \& reporting and planning, control \& reporting in projects [29]. An interesting question arises from the exploration of controllers' tasks, and this is 'role taking' versus 'role making'. In other words, the question is whether controllers do what management tells them to do, or controllers determine most of their tasks themselves. Weber and Schäffer argue that, within certain limits, controllers are able to define task focus areas and roles autonomously [52]. So, what has changed in the last 15 years in the function of controlling? Our results show continuous strengthening of operative tasks, followed by increasing frequency of strategic tasks. We could interpret this as better affirmation of controlling. On the other hand, we can interpret this also as a consequence of the financial and economic crisis in $2007 / 2008$ which lasted a few years longer in Croatia than in other EU countries, which further stresses the importance of controlling tasks.

\subsection{Instrumental aspects of controlling}

The level of development of controlling could be evaluated by a number of instruments. This subsection provides empirical results regarding the tools and methods which are frequently used in controlling departments. The main question is: Which controlling instruments and tools are most frequently used in companies in Croatia? The top 5 instruments used are: cost-effect comparison, indicators and system of indicators, comparison to competition, cash flow accounting and SWOT analysis. Those results reflect the dominant operative orientation of controlling with a slow shift to the strategic dimension (SWOT). The implementation of particular instruments depends on auxiliary means, e.g. spreadsheet programs, data banks, expert systems and controlling software programs. According to our research results, spreadsheet programs are the most frequently used means (from $89 \%$ in 2001 to $95 \%$ in 2015 ), followed by data banks (from $65 \%$ in 2001 to $57.5 \%$ in 2015) and expert systems from $11 \%$ in 2001 to $25 \%$ in 2015). Those means enable perfect operative planning and control but are not appropriate for the strategic dimension. So, what has changed in the period 20012015? Operative instruments widely prevail, its use in 2015 is stronger than before. There is also modest evidence of the use of strategic instruments, e.g. value analysis, product-market portfolio, sensitive analysis, etc. Because of contemporary business dynamics and complexity, more intensive use of strategic instruments would be welcome.

\subsection{Controlling information sources and users}

The controlling function can be explored by analysing the information flow: where does information necessary for controlling come from and where does it go then. In other words, who are the main users of controlling information? We got more insight into controlling and its information flow by asking the following question: What are the main information sources for controlling and who are the main users of information from controlling? Accounting is, no doubt, at the top, being the most used source of information (92\% in 2001 and 100\% in 2015). 
It is worthy to point out that accounting is a very wellstructured information source and always available. However, we have to stress that accounting reflects past - and in best cases - present business activities which can be expressed in physical or financial units of measure or hard facts. If we need information about possible future or soft facts, accounting becomes voiceless. And there is room for controlling which accepts the past and present situation but its focus is in future possibilities, where soft indicators are needed.

Besides accounting, finance, sales, supply and production are the next frequent sources of information in controlling. This finding reflects domination of monetary, hard facts and internal orientation as well. Environmental information was ranked 6th as a source, with light increase in use from $41 \%$ in 2001 to $45 \%$ in 2015.

The dynamic perspective of information sources used in the period 2001-2015 shows a stronger use of internal information sources: besides accounting, finance, supply and production in particular have become more important than before, those are the main sources from which information flows into controlling. We see it as the dominant internal and operative orientation regarding information sources.
The next question is where does information from controlling flow next? Our results show that management - top and lower - is the main internal user and it proves - a wide accepted stance that controlling is a management supporting function. Besides management, other important users of information from controlling are sales, external users, supply and finance. The information flow into and out of controlling is presented in Figure 6. Our findings show top 5 sources of information for controlling. It seems that management uses controlling information first in accounting, e.g. using quantitative information from the past or present situations. There is a practitioner's rule that says: for a business decision only $40 \%$ of information should come from accounting, and the remaining $60 \%$ of information should come from other internal and especially external sources. So, we can conclude that controlling in companies in Croatia is more past- and internally- oriented, which is the perfect orientation for stable and simple business circumstances such as those during the 1950s - 60s. In today's dynamic and complex business world, much more external information sources are needed, followed by information about future possibilities.

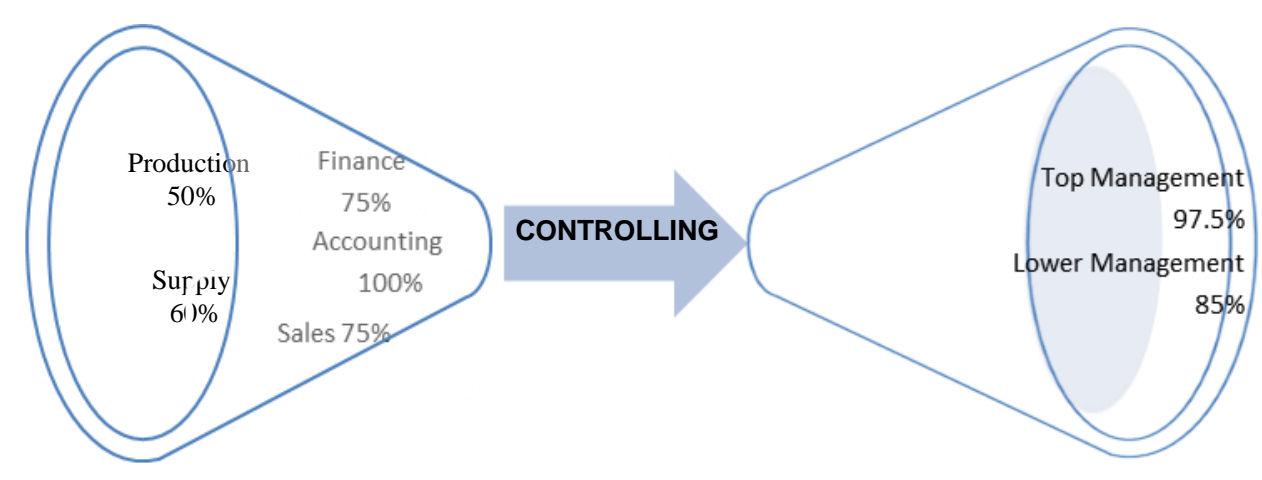

Figure 6. Controlling information flow

The dynamic perspective of the last 15 years reflects a stronger importance of managers as users of information from controlling, especially lower management. The good news is considerably increased role of sales, supply and finance as internal users on the one hand, and external users, on the other hand. It is well-known that bank experts appreciate the existence of a controlling department in an organization because there they can find information experts and a supporting interlocutor.

So, our findings also prove the increase in controlling users which reflects a wider acceptance of controlling in 2015 compared to 2001.

The summaries of our main findings in controlling regarding tasks, instruments, information sources and users in the period 2001-2007-2015 are presented in Figure 11. For this purpose, we point out the average frequency of top 5 tasks for each year, top 5 instruments, 5 main information sources and top 5 information users per year. The field of controlling tasks has experienced the most intensive change, the average frequency has risen significantly, which proves a wider acceptance of controlling tasks in the last 15 years. Unfortunately, controlling instruments do not follow the tendency of tasks. The average frequency of controlling instruments rose in the period 2001-2007 and then stopped on that level.

The logical question was: How could controlling execute more tasks with fewer instruments? That is possible only if controlling tasks grow faster than corresponding instruments. Incoming and outcoming information to and from controlling reflects the increasing average frequency of information sources and, at the same time, the stagnating average frequency of information users.

It seems that information sources have improved because of the rise of their average frequency, while information users have achieved their top frequency. 


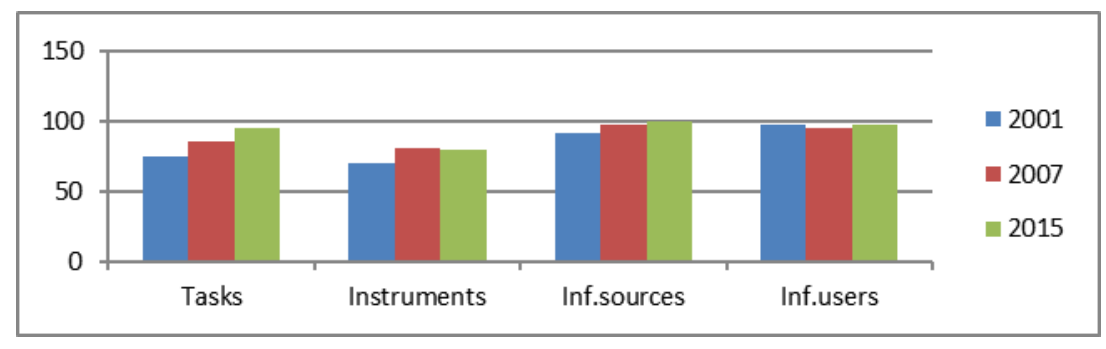

Figure 11. Controlling changes in years 2001-2015

The changes in controlling in the last 15 years are evident in the fields of controlling tasks and information sources, while there is a lack of development in controlling instruments.

\subsection{Contribution of controlling to business success}

Controllers' contribution to business success increases the more they orient their activities toward their internal customers, the manager [52]. Controlling demonstrates its effects only if it contributes to company performance and business success. Transparency is the key approach. Controlling sheds more light and awareness in the management process which is the precondition for accountable business success in the long-term. Controllers contribute to company performance in different ways [52]: new investment proposals have to meet profitability targets, new products are only included in the product range if they promise to improve results, and if managers do not achieve their targets they have to face unpleasant questions from controllers.

It is often claimed and empirically proven that controlling is a success factor $[50 ; 31 ; 15]$. The main question in our study is: How is controlling understood and does it contribute to business success?

Empirically, controlling is mainly understood as professional assistance to all tiers of managements, or shortly, as management expert support (77.5\%). Secondly, controlling is frequently seen as information support $(65 \%)$. Thirdly, it is seen as control and supervision $(52.5 \%)$, followed by planning and analysis substitute (42.5\%). In comparison, in German companies (Weber et al., 2006), management usually perceives controllers as an internal consultant (61.7\%) and economic conscience (52.7\%). Our findings reflect variations in how controlling is understood, present in theory and in practice as well. We can conclude that controlling is mainly understood as management support and information provider, which correlates with similar research studies [14].

From the dynamic point of view in the last 15 years, there is a significant shift of understanding of controlling toward management and information support, although the role of controlling as control and supervision was more accepted in 2015 compared to 2001-2007. We see this more as a lack of understanding of controlling than as a controlling role that has to be evaluated. Let us recall the Deng Xiaoping's quote at this point: "It doesn't matter whether a cat is black or white, as long as it catches mice." So, we want to discover if controlling contributes to business efficiency and business success. Otherwise, why would we need controlling? Our findings are very interesting and affirmative: in 2001 controlling was recognised as a business success factor by $97 \%$ of respondents, in 2007 by $93 \%$ and in 2015 by $100 \%$ of respondents. A very high percentage proves that controlling contributes to business efficiency and business success. Variations in percentages in the 15 years reflect a rising affirmation of controlling in companies in Croatia.

As empirical research proves, not only in Croatia, controlling is undoubtedly a success factor and contributes to business success as much as management allows it to [31].

\subsection{Relevance of controlling in the organization}

With our last question we aimed to get a clear perception of the importance of controlling in the organization. From our respondents' perspective, controlling is most important as a place of planning and analysis (4.48), and then an important source of information (4.15). Controlling is less important as consultant (3.53) and coordinator \& integrator (3.43). From the dynamic point of view, all dimensions have strengthened in the period studied, excluding planning and analysis. As already mentioned, in many organizations in Croatia former planning and analysis departments have become controlling departments. From that point of view, a weakening of that role of controlling and strengthening of other roles of controlling reflects a stronger implementation of the real controlling function.

\subsection{Incentives and obstacles to controlling development}

Finally, our aim is to explore the determinants of the future development of controlling. The research question is: Where are the main incentives and obstacles to the development of controlling? Basic incentives for controlling development could be internal 
and external. In 2015 our respondents estimated that $78.3 \%$ were internal and 21.7 were external incentives. Our findings demonstrate internal incentives as very important, especially the influence of management $(22 \%)$ and employees (13.9\%), while main external incentives are: external analysis $(30 \%)$, competition $(30 \%)$ and technology (20\%). So, if we want better controlling, the main influence is by management, since they are controlling service customs, and employees as controlling service providers. The market situation and technology stimulate the development of controlling additionally.

Management has a key role in controlling practice: since management is controller's 'custom', they decide about controlling conception, scope and performance. Controller tasks are determined by manager's characteristics, namely manager's motivation and abilities [52]. Therefore, management is the main stimulus - or limitation - to controlling. Empirical research in Croatian companies shows that the main impulse for controlling implementation comes from management $(64 \%$ in 2001 and $54 \%$ in 2007) [28].It would be interesting to find out if there are elements that hinder the development of controlling. Our respondents estimate that internal barriers (89.7\%) are much stronger than external ones (10.3\%). The most important internal obstacles are IT support (22.9\%), management $(20 \%)$, lack of understanding and knowledge (17.1\%) and employees (11.4\%). So, if we want better controlling, we have to invest into IT support and spread knowledge about controlling. External obstacles are present too, but they are much less important than the internal ones. However, it is good to know that they exist. To sum up, on the way to better controlling we have to spread its understanding, knowledge and benefits to management and to employees as well.

\section{CONCLUDING REMARKS}

This paper provides empirical research results related to controlling in companies in Croatia in the period 2001-2015. The aim of this study is to provide empirical evidence on controlling in companies in Croatia. Our guiding question has been: "What does the reality of controlling in Croatian companies look like and how has it changed in the last 15 years?" This study is a longitudinal study that enables the observation of different dimensions in the evolution of controlling. The contributions of this paper are multiple. The first contribution covers the understanding and role of controlling in practice, its function, instruments, information flow, contribution to business success and incentives/barriers. The second one covers evidence of dynamic experience of controlling in Croatian companies in the last 15 years. And the third one covers the methodological approach for individual comparisons and benchmarks. This study also provides theoretical and empirical contributions. From the theoretical point of view, this paper offers the academic community interesting insights into the empirical understanding of controlling and its changes, thus contributing to the existing literature. From the empirical point of view, this study with its relevant results, provides understanding and learning from the practice, thus enabling national and international comparison of controlling experiences while offering a basis for comparison.

The role of controlling as important expert management support is recognised in Croatian companies. This latest research, just like research studies before, reflects the dominance of operative tasks and instruments, neglecting strategic and normative business aspects. These results give a clear sense of operative controlling as widely present but show that there is a need for strategic and normative aspects as well. The relationship between the manager and controller undoubtedly makes all the difference so that managers give impulses or set limits to controlling performance and development and have the main role in the implementation of controlling.

The target audience for this paper includes scholars who may find inspiration in this new research idea and its discussion. Because our results originate from the controlling practice, this study could be interesting for managers and owners, members of supervisory boards and experts as well.

This paper provides the past and current view, together with the future outlook for the development of controlling. Controlling has indeed become so widely accepted that it is worth researching more deeply. International comparison and benchmarking provide additional knowledge and help to improve particular business practise. There are several directions for further research: exploring controlling in small/medium companies, different branches and in different countries, in non-profit organizations, developing controlling benchmarks, researching crisis controlling and sustainability controlling. The academic community is therefore summoned to explore new trends and help in their implementation.

\section{REFERENCES}

[1] Anthony, R.N. (1988), The Management Control Function, Boston Anthony, R.N., Dearden, J. (1976) Management Control System, Homewood, Illinois

[2] Baier, P., (2008), Praxishandbuch Controlling, Moderne industrie, München

[3] Buchholz, L. (2013) Strategisches Controlling, Springer, Gabler, Wiesbaden

[4] Dobroszek, J. (2016) Analysis of Factors Affecting the Implementation of Controlling in Logistics Enterprises and the Resulting Effects - Case of Poland, Elsevier, Procedia, ScienceDirect 213, pp.248-253

[5] Döpke, U. (1986) Strategisches Marketing Controllership, Frankfurt/Bern/New York

[6] Eschenbach, R., Siller, H. (2009) Controlling professionell, Konzepte und Werkzeuge, Schäffer-Poeschel, Stuttgart

[7] Fulanović, D. (2012) Strategijski kontroling u poduzećima mesoprerađivačke industrije u Republici Hrvatskoj, magistarski rad, Ekonomski fakultet Zagreb

[8] Hausser, L. (2016) Controlling in Mittelständischen Unternehmen in Russland: Theoretische Betrachtung, Empirische Untersuchung Und Konzeptionelle Empfehlungen, Springer, Gabler

[9] Horak, Ch., Keinz, P., Furtmüller, S. (2004) Controlling in österreichischen Nonprofit- Organisationen. Eine empirische Bestandsaufnahme, Controller News 2006, 6, p.183186

[10] Horvath, P. (1991), Controlling, Vahlen, München 
[11] Jakelić, D. (2011) Uloga kontrolinga u procesu poslovnog odlučivanja u središnjem bankarstvu, doktorska disertacija, Ekonomski fakultet Zagreb,

[12] Jung, H. (2011), Controlling, Oldenbourg, München

[13] Kaland, A. (2014) Controlling im Facheinzelhandel, Josef EUL Verlag, Lohmar-Köln

[14] Kosmider, A. (1991) Controlling im Mittelstand - Ergebnisse einer empirischen Untersuchung, Vallendar

[15] Krčmar, D., (2009), Uvođenje kontrolinga u srednja poduzeća industrije hrane i pića, Magistarski rad, Ekonomski fakultet Zagreb

[16] Kunz, J. (2003) Einführung, in: Weber, J., Kunz, J. (Hrsg) Empirische Controllingforschung: Begründung-Beispieleergebnisse, Schriften des Center for Controlling \& Management (CCM), Band 8, Gabler, Wiesbaden

[17] Küpper, H.U. et al (1990), Zum Verständnis und Selbstverständnis des Controlling, ZfB, Gabler, Wiesbaden, Nr.3, p.287

[18] Landsberg, G.v., Mayer, E. (1988) Berufsbild des Controllers, Stuttgart

[19] Legenhausen, C. (1998) Controllinginstrumente für den Mittelstand, Springer

[20] Lingnau, V. et al, (2018) Empirische Forschung im Controlling: Ein Leitfaden, Beiträge zur Controlling-Forschung, No. 27 http://hdl.handle.net/10419/175422

[21] Makaj, N. (2011) Kontroling u leasing društvima, Ekonomski fakultet Zagreb, specijalistički poslijediplomski rad

[22] Mödritscher, G. (2015), Planning and Managerial Accounting in Austria - Lessons Learned and developments over the past 30 years, 8th Conference on Performance Measurement and Management Control, EIASM, Nice, France, September 30 October 2, 2015, p.4

[23] Niedermayr, R. (1994) Entwicklungsstand des Controlling: System, Kontext und Effizienz, Wiesbaden

[24] Niedermayr, R. (1995); Die Realität des Controlling, p.125-168 in: Eschenbach, R. (Ed) (1995), Controlling, Schäffer-Poeschel, Stuttgart

[25] Ortelbach, B, Hagenhoff, S. (2004) Entwicklungen und Perspektiven der Controllingforschung, Arbeitsbericht $\mathrm{Nr}$. $17 / 2004$, Institut für Wirtschaftsinformatik, Georg-AugustUniversität Göttingen, http://webdoc.sub.gwdg.de/ebook/serien//m/arbeitsberichte_wi2/ 2004_17.pdf

[26] Osmanagić Bedenik, N. (2003) The Reality of Controlling in Croatia - Preliminary Results of the Empirical Research, Zbornik Ekonomskog fakulteta u zagrebu, god.1, broj 1, 2003, p. 177198

[27] Osmanagić Bedenik, N. (2007a) Comparative Analysis of Research on Controlling in Croatia, Zbornik Ekonomskog fakulteta u Zagrebu, god.5, 2007, p.361-385

[28] Osmanagić Bedenik, N. (2007b) Kontroling - Abeceda poslovnog uspjeha, Školska knjiga, Zagreb, p. 46-78

[29] Osmanagić Bedenik, N. et al, (2010), Kontroling između profita održivog razvoja (Controlling between Profitability and Sustainability), M.E.P. Zagreb

[30] Osmanagić Bedenik, N. (2015) The Challenge of Controlling, International Journal of Industrial Engineering and Management (IJIEM), Vol.6 No 4, pp.153-163

[31] Osmanagić Bedenik, N., Lalovac, B., (2007), Kontroling - faktor poslovnog uspjeha, Primjer hotelskih poduzeća (Controlling Factor for Business Success, An Example from the Hote Industry), Acta turistica, Ekonomski fakultet Sveučilišta u Zagrebu (Faculty of Economics, University of Zagreb), Vol. 19/2007. p. 83-99.

[32] Osmanagić Bedenik, Lizzul (2015a), Obilježja kontrolinga u dioničkim društvima na Zagrebačkoj burzi, Zbornik Ekonomskog fakulteta u Zagrebu, Vol.13 No.1, p.115-128

[33] Osmanagić Bedenik, N., Lizzul, A. (2015b) , Komparativna analiza obilježja kontrolera u poduzećima koja kotiraju na zagrebačkoj i frankfurtskoj burzi, WPS, EFZG, (https://ideas.repec.org/p/zag/wpaper/1511.html)

[34] Ossadnik, W. (2003) Controlling, 3.Aufl. Wien

[35] Peemöller, V.H. (1990), Controlling, Neue Wirtschaftsbriefe, herne, Berlin

[36] Perović, V., Osmanagić-Bedenik, N., Bojanić, R. and TodorovićDudić, A., (2016), Recent situation of controlling in Serbia and comparation with its implementation in Croatia, AUDITOR, 19
(76), pp. 39-48. Available at: http://revizor.ief.rs/index.php/revizor/article/view/78 ISSN: 2620 1461

[37] Reichmann, T., Kleinschnittger, U. (1987) Controlling-Funktion in der Unternehmenspraxis, In. ZfB 11/1987, PP1090-1120

[38] Roguljić, A. (2013) Međunarodni benchmarking kontrolinga u poštama Hrvatske, Austrije i Slovenije, Ekonomski fakultet Zagreb, specijalistički poslijediplomski rad

[39] Ruda, W., Dackiw, B. (2015) Controlling in Germany from the View of Practitioners and Students - An Empirical study, Management, Enterprise and Benchmarking in the 21st Century,

[40] Siller, H. (2011) Normatives Controlling, facultas wuv, Wien

[41] Schäffer, U., Weber, J. (2003) Thesen zum Controlling (II), CCM-Forschungspapier Nr. 8, Vallender

[42] Stoffel, K. (1995), Controllership im internationalen Vergleich, Wiesbaden

[43] Šarac, M. (2013) Primjena kontrolinga u bankama, Ekonomski fakultet Zagreb, specijalistički poslijediplomski rad

[44] Šestanj-Perić , T. (2010) Specifičnosti kontrolinga u malim i srednjim poduzećima, magistarski rad, Ekonomski fakultet Zagreb

[45] Šimunić, D. (2011) Instrumenti kontrolinga u malim poduzećima, magistarski rad, Ekonomski fakultet Zagreb

[46] Tramm, A. (2016) Finanzcontrolling in der Unternehmenspraxis: Eine empirische Analyse über die funktionale Ausgestaltung unter Berücksichtigung institutioneller Einflüsse, Unternehmensrechnung und Controlling, Band 14, BoD, Norderstedt

[47] Weber, J. (2009), Erfolg der Controller, Wiley-VCH, Weinheim

[48] Weber at al, (2006), Controlling 2006: Stand und Perspectiven, Vallendar, („ICV study“)

[49] Weber, J., Schäffer, U., (1999) Sicherstellung der Rationalität von Führung als Aufgabe des Controlling? DBW 59 (1999), 6, p.732:

[50] Weber, J., Schäffer, U.Langenbach, W. (1999) Gedanken zur Rationalitätskonzeption des Controlling, WHU-Forschungspapier Nr. 70, Vallender

[51] Weber, J. (2007) Von Top-Controllern lernen: Controlling in den DAX 30-Unternehmen, Wiley-VCH,Weinheim

[52] Weber, J. Schäffer, U. (2008) Introduction to Controlling, Schäffer-Poeschel, Stuttgart

[53] Weber, J., Schäffer, U. (2014) Einführung in das Controlling, Schäffer/Poeschel, Stuttgart

[54] Weber, J., Zubler, S. (2010), Controlling in Zeiten der Krise, Wiley-VCH, Weinheim

[55] http://dictionary.reference.com/browse/control

[56] https://scholar.google.hr/scholar?q=controlling+empirische+unter suchungen\&hl=en\&as_sdt=0\&as_vis $=1$ \&oi=scholart 


\title{
Evolucija kontrolinga u preduzećima u Hrvatskoj - Longitudinalna studija
}

\author{
Nidžara Osmanagić Bedenik, Mirjana Pejić Bach
}

Primljen (27.11.2018.); Recenziran (29.01.2019.); Prihvaćen (19.02.2019.)

\begin{abstract}
Abstrakt
Kontroling je prvenstveno fenomen koji se nalazi u praksi. Interesantno pitanje o tome kako se kontroling razvija u praksi, dobilo je respektabilnu pažnju u istraživanju i odgovarajućoj literaturi. U ovom radu istražujemo kontroling u svetlu empirijskih istraživanja. Štaviše, neistraženo pitanje kako se kontroling razvija u praksi u Hrvatskim kompanijama je glavna inspiracija za ovaj rad. Cilj ovog rada je da pruži uvid u ulogu kontrolinga i njegovo razumevanje, funkciju, zadatke, instrumente i protok informacija. Analiziramo uočeni doprinos kontrole poslovnom uspehu, kao i podsticaje i prepreke njegovom razvoju. Ova studija se zasniva na analizi primarnih podataka sa ciljem opisivanja razvoja kontrolinga (eksplorativne studije). Istraživanje pokriva vremenski raspon od 15 godina u tri različite vremenske tačke: 2001., 2007. i 2015. godine. Studija je ujedno i istraživanje trendova jer omogućava analizu promena na nivou istraživačkog uzorka. U ovom radu posmatramo, opisujemo i objašnjavamo nalaze kontrolne prakse u Hrvatskim kompanijama. Naši rezultati pokazuju da se kontroling u Hrvatskim kompanijama najčešće shvata kao osiguranje racionalnosti upravljanja. Generalno, operativni zadaci i operativni instrumenti dominiraju interno orijentisanim fokusom. Ono što je još uvek potrebno je više strateška i normativna orijentacija, više spoljašnje orijentacije $i$ više slobode za kontrolore da kreiraju zadatke $i$ aktivnosti. Kontroling je takođe prepoznat kao faktor poslovnog uspeha u Hrvatskim kompanijama. Menadžment ima glavni uticaj na razvoj kontrolinga, dok je IT podrška otkrivena kao glavna prepreka u njenom razvoju. Doprinos ovog rada je trostruki: prvo, pruža uvid u kontrolnu funkciju; drugo, istražuje dinamičku perspektivu u kontrolingu u poslednjih 15 godina u Hrvatskim kompanijama, i treće, ovim radom se nadamo da ćemo dati smernice za dizajn i preporuke koje treba konkretizirati u organizacijama uzimajući u obzir specifične uslove svakog pojedinačnog slučaja.
\end{abstract}

Ključne reči: razumevanje kontrolinga, kontrolni zadaci, kontrolni instrumenti, podsticaji protoka informacija $i$ prepreke, Hrvatske kompanije 